Vol. 1, No. 1, 2019

https://doi.org/10.23939/cds2019.01.071

A. Zdobytskyi, O. Matviykiv, M. Lobur, T. Klymkovych, N. Bokla

Lviv Polytechnic National University

\title{
PORTABLE SYSTEM FOR SAMPLING LIQUID ATMOSPHERIC PRECIPITATION
}

(C) Zdobytskyi A., Matviykiv O., Lobur M., Klymkovych T., Bokla N., 2019

The paper considers the possibility of determining the permanent and random sources of pollution of the environment by the level of pollution of liquid atmospheric precipitation. The problems of liquid atmospheric precipitation testing and monitoring of pollution concentration during precipitation are outlined. The expediency of developing of a portable system that allows collecting samples of liquid atmospheric precipitation in autonomous modes at different time intervals and periods of rainfall, regardless of the place of its installation, is substantiated. The design features of the electric and mechanical parts of the device, as well as the algorithm of their work, are described. The results of modeling and checking of the working capacity of the portable device, which determine the total mass flow of water, are described.

Key words: atmospheric precipitation, portable system, device, drive gear, sampling, pollution, control board, sensor.

\section{Formulation of the problem}

Monitoring and recording of ecosystem data provide foresight and timely detection of negative environmental factors that cause contamination.

The sampling of any material is an extremely important issue since it is susceptible to contamination arising from the use of not clean enough laboratory equipment, impurity and other atmospheric contamination.

Liquid atmospheric precipitation usually includes a variety of impurities, which, along with water, fall on different surfaces and get into the soil. This, in its turn, may have a negative effect, since most industrial or other emissions have unknown composition. Therefore, it is inappropriate to carry out atmospheric precipitation sampling in the vicinity of various industrial sites.

It will be more effective to sample liquid atmospheric precipitation in different parts of a settlement and beyond, which will enable the establishment of permanent and accidental sources of pollution, as well as the concentration of the emissions $[10,11]$.

\section{Actuality of research}

Usually, sampling of atmospheric precipitation is carried out by filling special containers made from neutral materials. Rainwater precipitation is collected with the help of the opening (diameter not less than $20 \mathrm{~cm}$ ) into a measuring cylinder (or directly into a bucket) and stored in them up to the analysis.

A significant disadvantage of this method of sampling is that the concentration of impurities is gradually decreasing, which makes it difficult to establish their origin and the nature of their occurrence for long periods of precipitation.

Therefore, there is a need for the application of small-sized portable devices that are capable of carrying out sampling of liquid atmospheric precipitation and their registration at different time intervals and periods of rainfalls in an autonomous mode, regardless of the place of installation, the seasons and the period of the day $[3,7]$. 


\section{Creating the objectives and objectives of the article}

Having analyzed the methods and means for taking samples of atmospheric precipitation, it has been established that at present there are many devices and means that are capable of collecting observations of precipitation and send out the results of a GSM modem, but have a number of advantages and disadvantages [5].

Some devices are too cumbersome and inaccurate. A number of devices collect data according to a certain algorithm and in certain periods of time we can only obtain a result of the amount and percentage of pollution from the total rainfall.

As a result, the development of a portable device that would be able to work autonomously and carry out the sampling of atmospheric precipitation, taking into account the time characteristics of precipitation, arose.

\section{Analysis of last researches and publications}

During the selection of precipitation, the possibility of entering into a sample of foreign substances should be excluded. A standard gauge made of chemically unstable material is unsuitable for this purpose. When manual sampling method is used, devices installed only for the period of precipitation. For analysis it is important to assemble the first, most contaminated portions of precipitation, so weather stations should provide a round-the-clock mode of operation. When automatic sampling of precipitation samples is used, the device is equipped with a device that automatically opens the lid located above the receiving surface at the beginning of precipitation and closes it after it has stopped. It provides measurement of the $\mathrm{pH}$ and electrical conductivity of precipitation.

\section{Submission of basic materials}

The development of a portable device for the collection of liquid atmospheric precipitation to monitor the change in their composition makes it possible to remotely obtain water samples for the rapid detection of contamination [6].

Functional scheme of the collection of samples of liquid atmospheric precipitation is presented in Fig. 1.

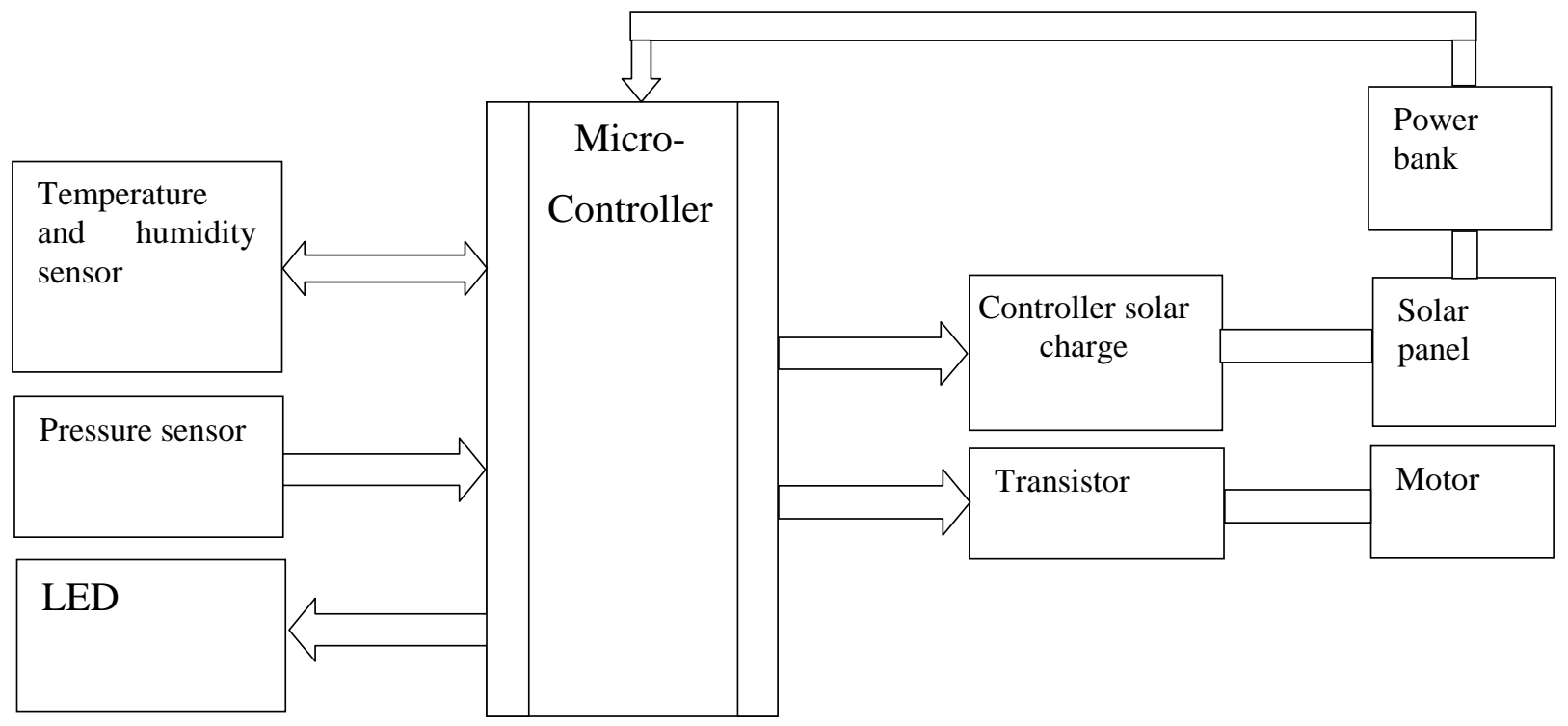

Fig. 1. Functional scheme of the system of sampling of liquid atmospheric precipitation 
In its turn, the system for sampling liquid atmospheric precipitation consists of electric and mechanical parts.

The electrical part of the device is intended for its machining and display of data on the changes in the composition of atmospheric precipitation taking into account the time factor (Fig. 2). The device consists of a control board Arduino UNO-R3 1 with a power supply 12VDC 2and a USB cable, a DC motor ROB-11696 3, a solar panel 6V1W4, a charge cell TP40565 and an energy storage USB Battery Pack, which is not specified in the diagram, a temperature sensor BMP180 6, an analog pressure sensor SEN0257 7, a modular water level sensor ZC09200 8, LED RGB Strip-Bare indication devices, and solenoid valve 1528-1551-ND $10[4,5]$.

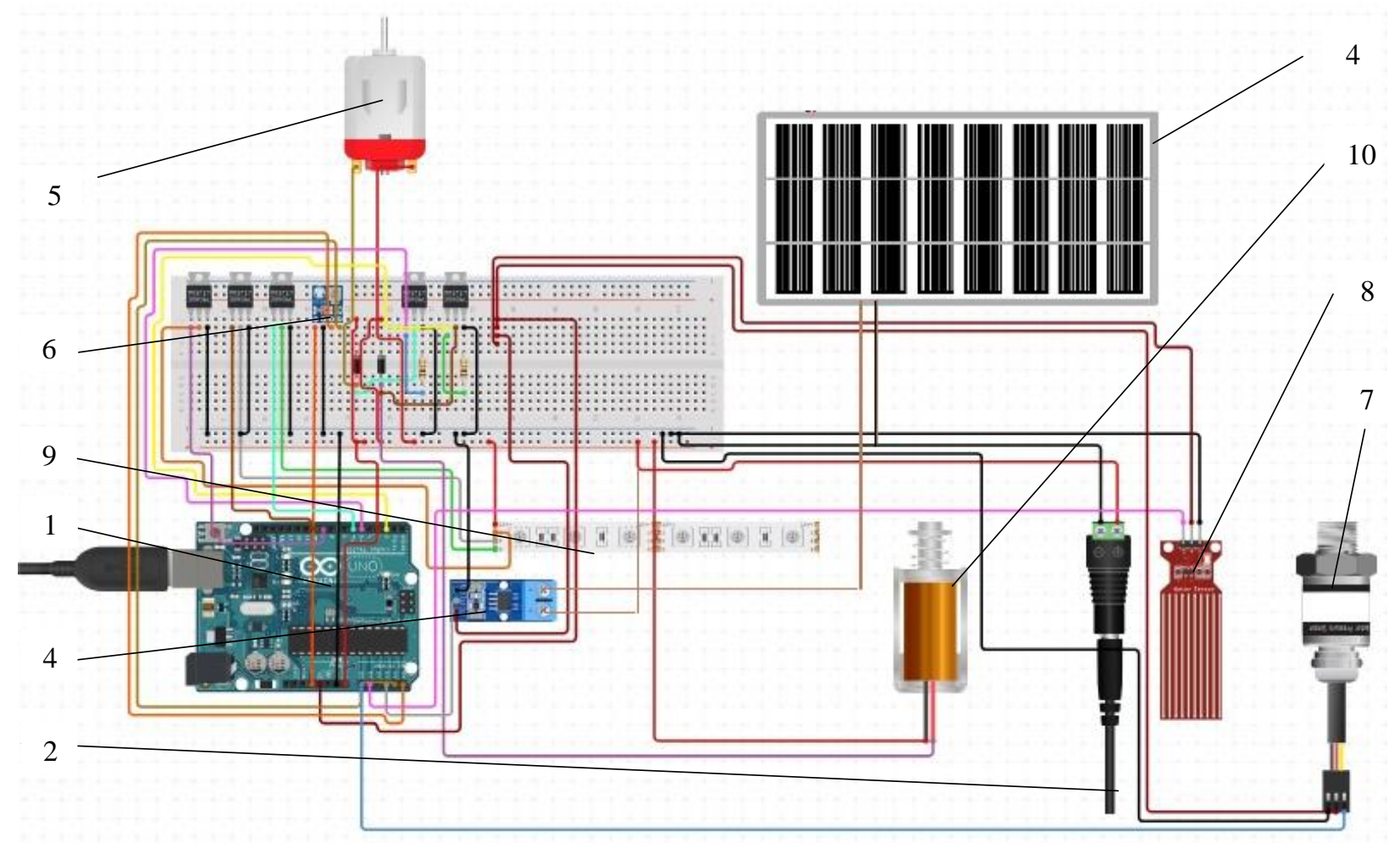

Fig. 2. Principal electrical circuit of a portable device for sampling atmospheric precipitation

The mechanical part of the device for collecting rainwater samples (Fig. 3) consists of a cylindrical hull 1 , in the bottom of which six samplers 2 are mounted, and the electric DC motor 3 is fixed, on the shaft of which the impeller of the water pump 4 and the gear wheel 5 are fixed. A dosing damper 6 is installed above the samplers, and the hull is closed at the top with a lid 7 with a tapered filler neck 8 with a lid $9[2,8]$.

The algorithm of the device is as follows:

During liquid atmospheric precipitation, water drops enter the modular water level sensor 8 (see Fig. 2), which results in the signal from the control board 1 to the solenoid valve 10, which opens the lid of the filler neck 9 and through it, enters the hull 1 (see Fig. 3). After that, the current is supplied to the electric motor 3, which activates the impeller of the water pump 4, together with the gear wheel 5, which, in turn, activates the dosing damper 6 . The water under pressure created by the water pump 4 is directed by flow to the samplers 2 . The dosing damper rotating gradually overlaps the supply of water in the first sampler and opens the feed into the second, then the third, fourth, and fifth samplers. Having fitted the hole of the dosing damper over the last hollow sampler, the actuator of the water pump and the gear wheel are disconnected, causing rainwater to flow out and the sampling is stopped. 

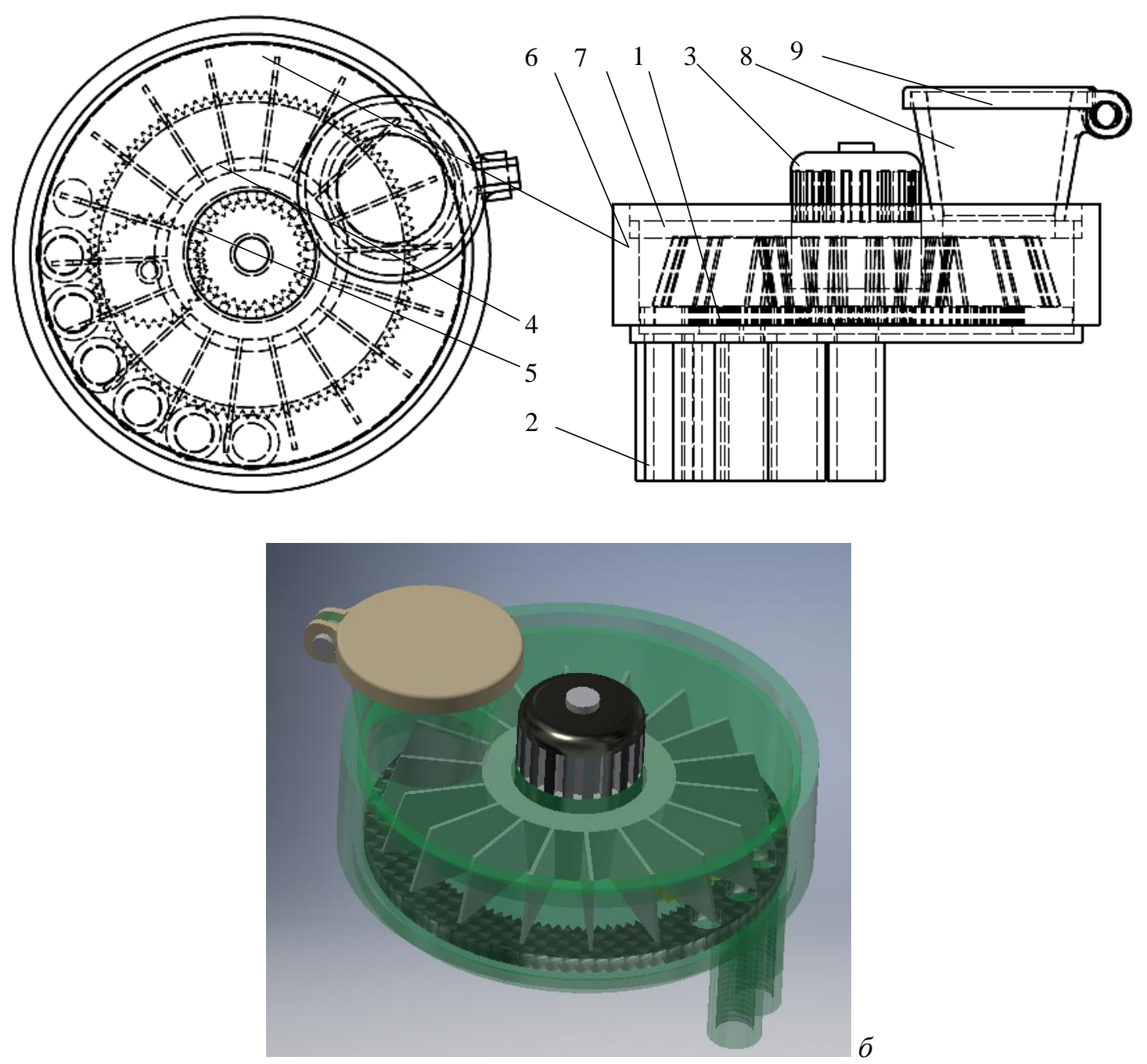

Fig. 3. Portable device for sampling atmospheric precipitation: a constructive diagram; б. general view

Simultaneously, for registering the water pressure and its temperature by the control board 1, pressure 6 and temperature 7 sensors, fixed in the cylindrical hull 1 of the device (see Fig. 3, 4) are switched on (see Fig. 2), and for the visual display of precipitation pollution the LED RGB Strip 10.

For the autonomous and uninterrupted operation of the portable device for sampling atmospheric precipitation on the lid of a cylindrical hull 7 (see Fig. 3), a solar panel 4 (see Fig. 2) is installed, the current from which flows through the charge control module 5, to the power storage, programmed by the board 1 .

Power supply 2 in cloudy weather conditions recharges a little the energy storage. In sunny weather conditions, the charge current from the solar panel 4 acquires the regulatory values, as a result, the control board 1 through the charging control module 5 disconnects additional charge.

To check the workability of the portable device and simulate the technological process of sampling atmospheric precipitation, we use the software product ANSYS (Fig. 4) [1, 12].

We set boundary conditions that the flow is open and depends on the water pressure, frequency of rotation of the impeller is $50 \mathrm{rpm}$.

Under these boundary conditions, we obtain the following distribution of the fluid pressure created by the impeller on the walls of the body (Fig. 5), as well as its moving speed (Figs. 4-7).

As we see from the concentration fields, the intensity of the increase of pressure occurs at the place of collection of liquid atmospheric precipitation and is $6.034 \mathrm{~Pa}$. 


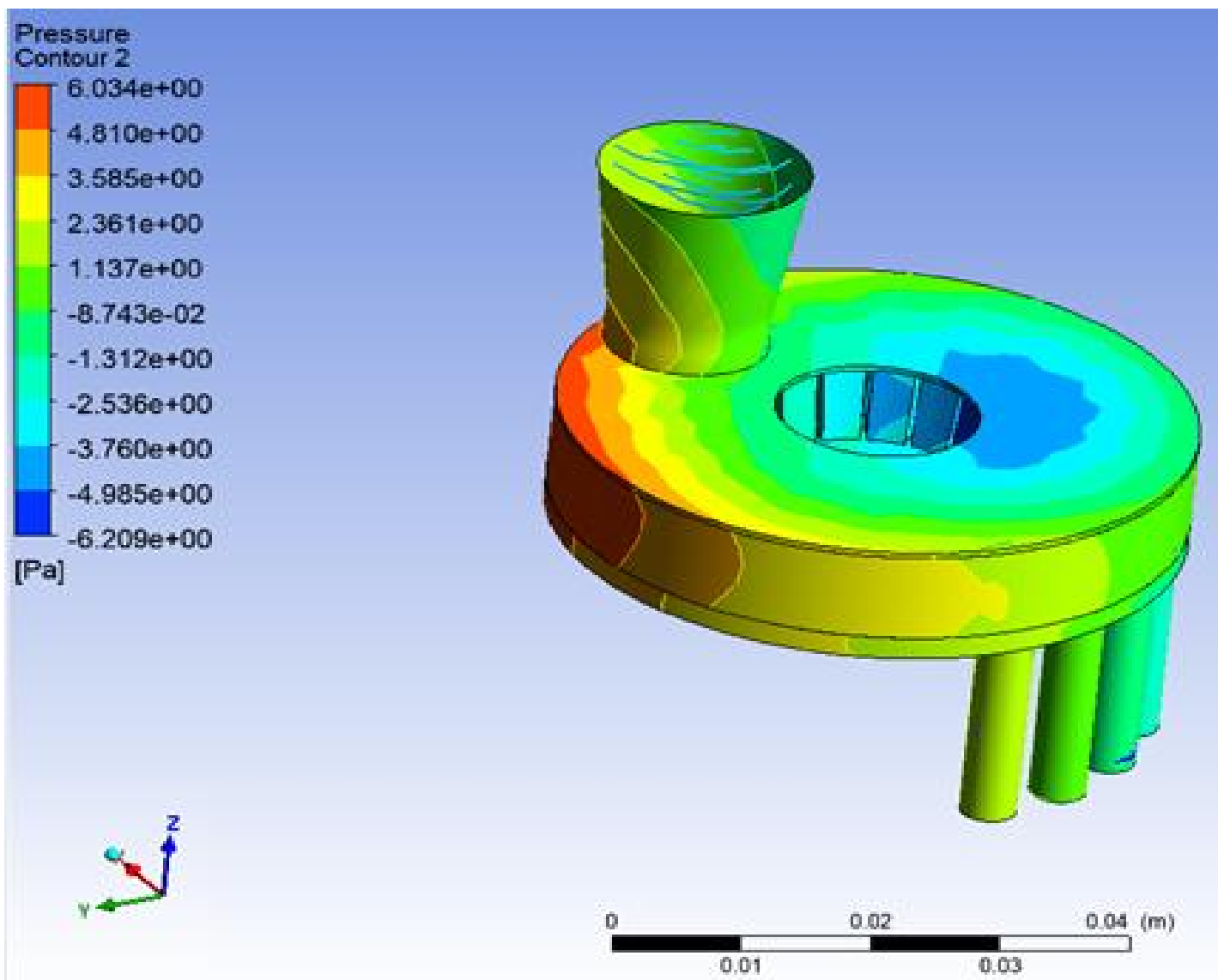

Fig. 4. The distribution of the pressure of the fluid created by the impeller on the walls of the hull
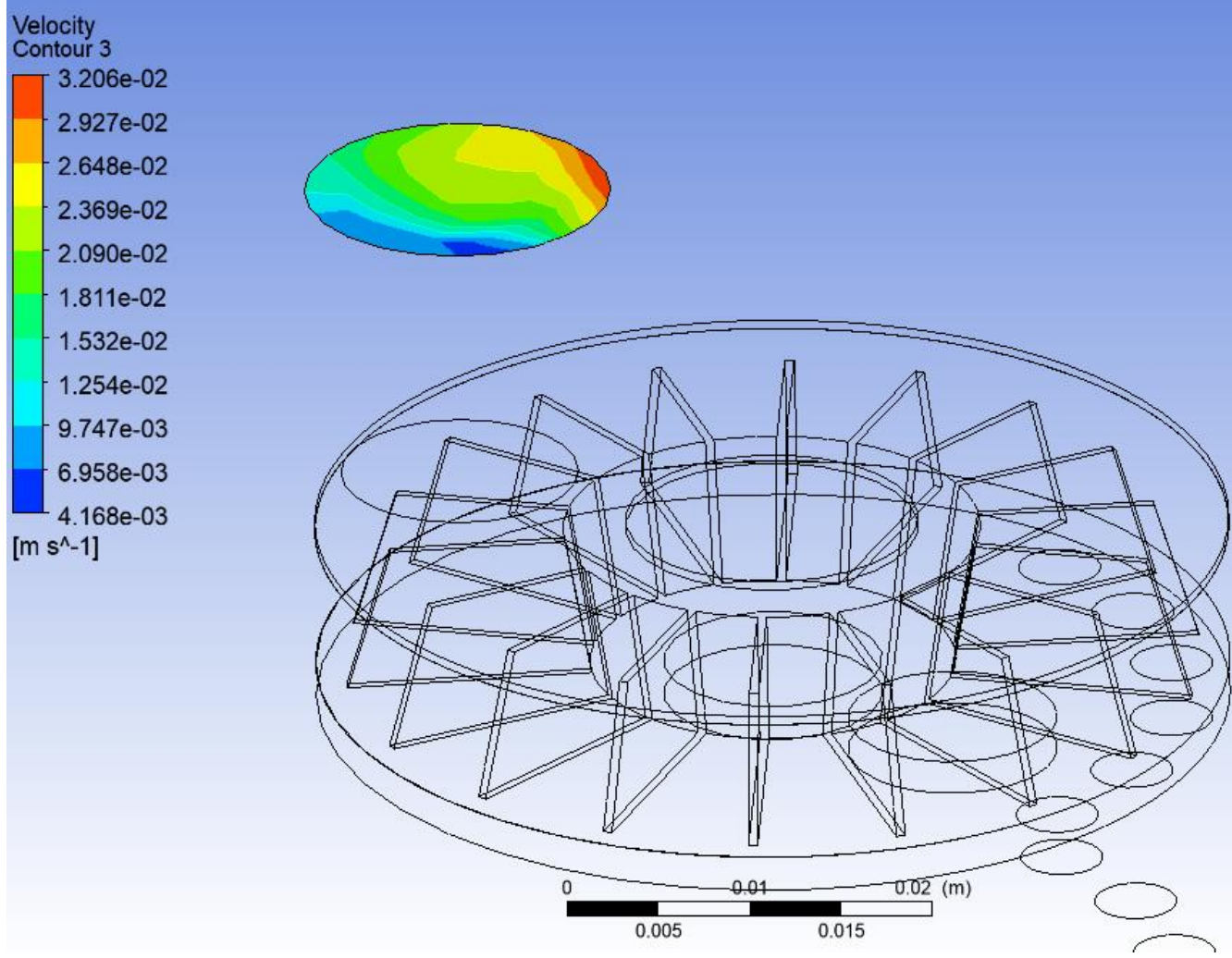

[m s^-1]

Fig. 5. The distribution of fluid flow rate at the entrance to the portable device 


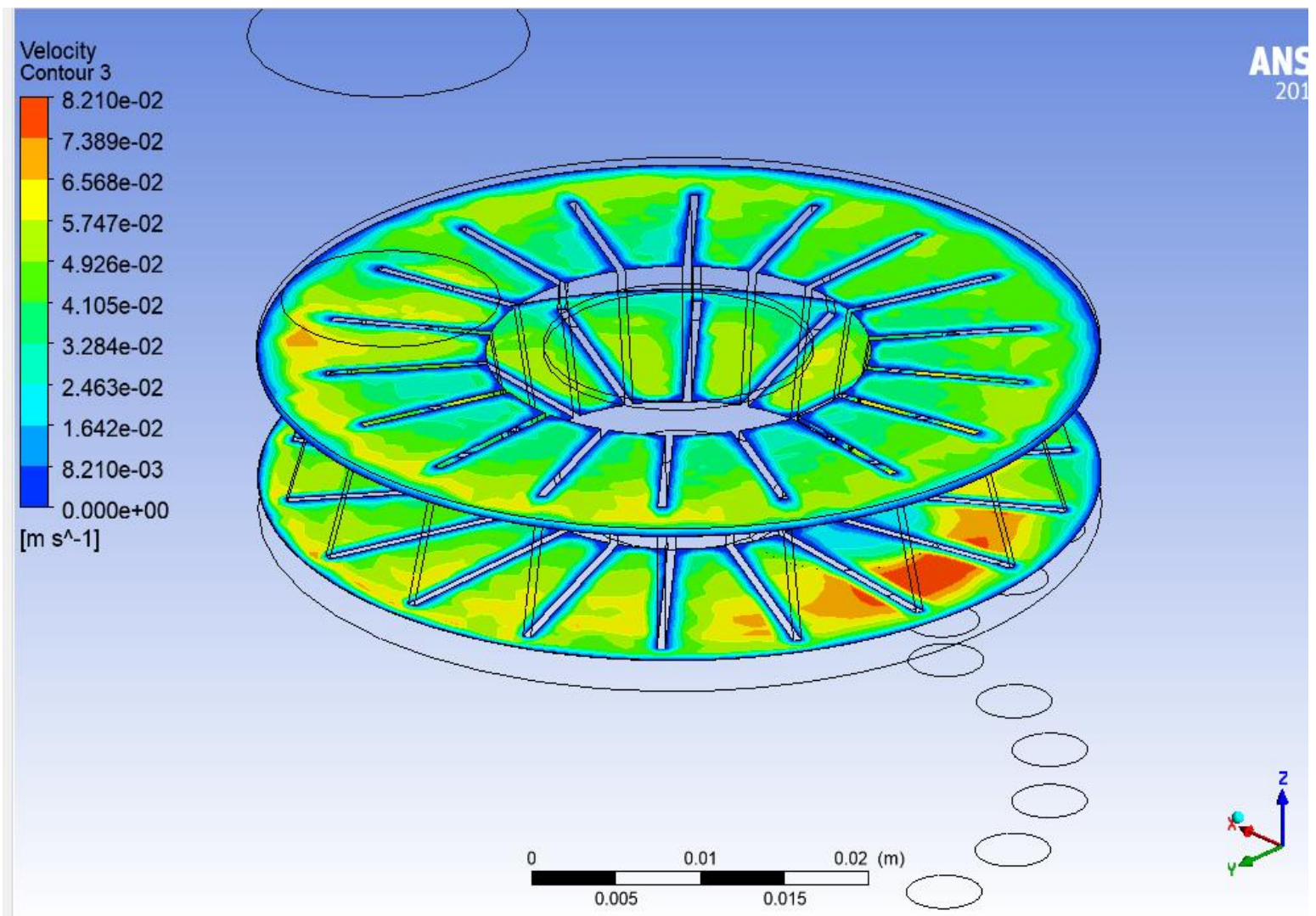

Fig. 6. The distribution of the velocity of the fluid created by the impeller in the hull of the portable device

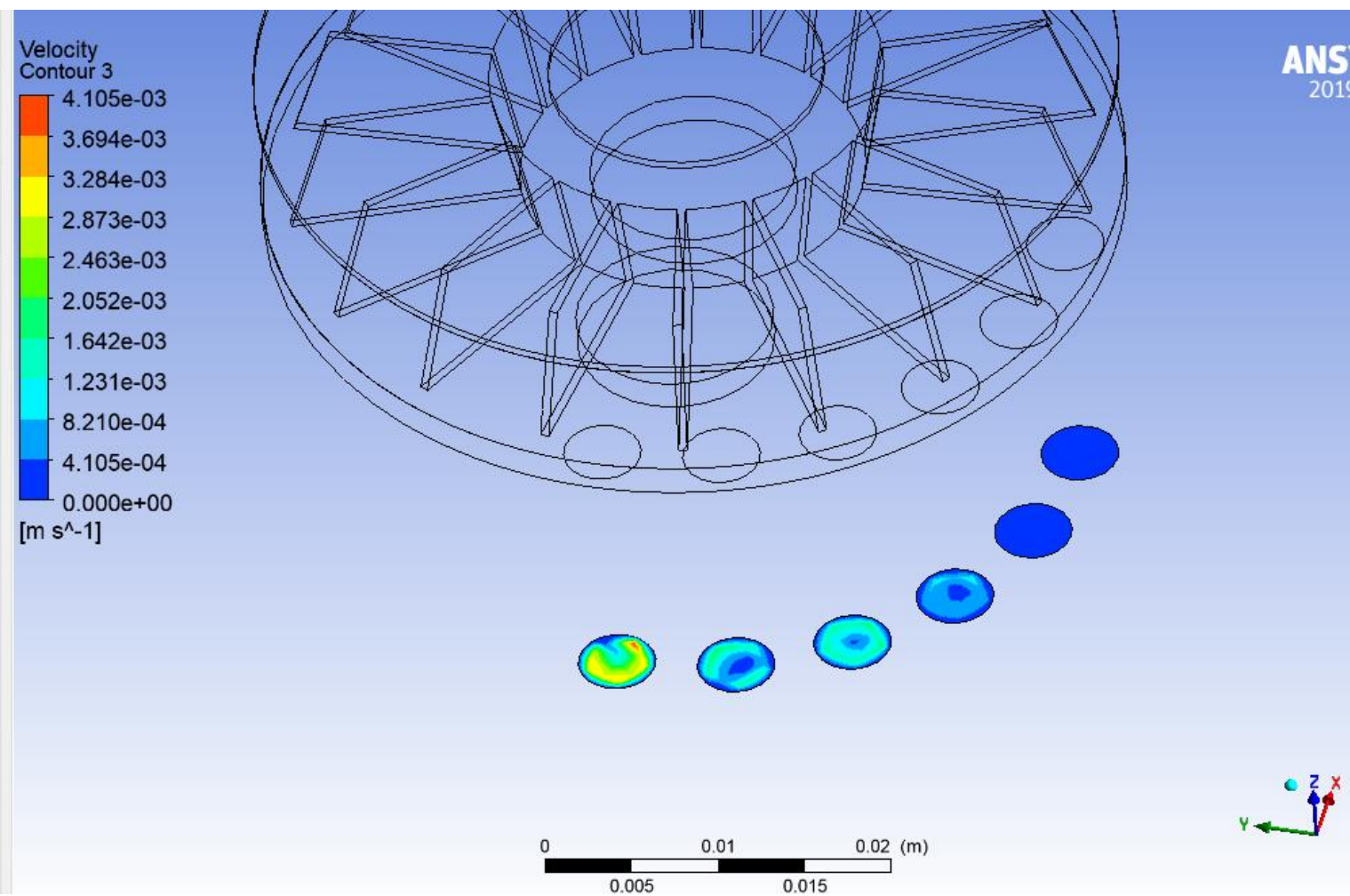

Fig. 7. The distribution of the flow rate of the liquid at the entrance to the samplers 
As can be seen from the results of the modeling of the operation of the device (Fig. 6-8), the fluid flow acquires the maximum values at the output of the hull of the portable device and is $0.082 \mathrm{~ms}^{-1}$.

\section{Conclusions}

The article considers the possibility of solving the problem of environmental monitoring of constantly operating and accidental sources of pollution of the environment by the level of pollution of liquid atmospheric precipitation.

The design of a portable system is substantiated, which makes it possible to obtain samples of liquid atmospheric precipitation in different time intervals, regardless of the location of the device.

According to the results of modeling and checking, the workability of the portable device, it is determined that the intensity of the pressure increase occurs at the place of collection of liquid atmospheric precipitation and is $6.034 \mathrm{~Pa}$, and the total mass flow of water is $0.00125646 \mathrm{~kg} \mathrm{~s}^{-1}$.

\section{Perspectives for further studies}

In the future, in further research, it is necessary to simulate the design parameters of the device and to generate its optimal form at a known pressure of the liquid on the walls of the body, the working bodies and the device in general. It is also necessary to make a prototype device and experimentally check its robustness. Perform a comparative analysis of the results of modeling the device with the results obtained experimentally.

1. ANSYS FLUENT Tutorial Guide. ANSYS Inc.: Southpointe, 2011. 1146 p.

2. Banach D. T., Jones T., Kalameja A. J. Autodesk Inventor 2010 Essentials plus Clifton Park, NewYork: Delmar Cengage Learning Autodesk Press, 2010

3. Columbia-Weather. "Pegasus EX PortableWeather Station - Columbia WeatherSystems, Inc." http://www.columbiaweather.com/Pegasus EX-Brochure.pdf June 3, 2010.

4. Depa K., Melnyk O., Melnyk M., Bokla N., Lobur M. The autonomous power supply for systems of acoustic climate control and traffic flows. 2018 XIV-th International Conference on Perspective Technologies and Methods in MEMS Design (MEMSTECH) Polyana, UKRAINE, 18-22 April, 2018 p. 268-271.

5. Garg S., Chaudhary A., Pradhan A., Sharma H. "The role of zigbee technology in weather monitoring system", International Journal of Advanced Research in Electrical, Electronics and Instrumentation Engineering Vol. 2, Issue 5, May 2013

6. Flues M., Hama P., Lemes M. J. L., Dantas E. S. K. and Fornaro A., An automatic refrigerated sequential precipitation sampler, Atmospheric Environment, 36, 2002.

7. Haefke M., Mukhopadhyay S. C. and Ewald H., "A Zigbee Based Smart Sensing Platform for Monitoring Environmental Parameters", 2011 IEEE.

8. Klimchuk S., Naumenko A., A. Tikhonov, A. Martynenko Automated design of agricultural machinery in the environment: Tutorial. Kharkov: KNTUA, 2005.

9. Matviykiv O., Klymkovych T., Bokla N. Modeling and analysis of integrated precise joule micro-heater for lab-chip diagnostic devices. 2018 XIV-th International Conference on Perspective Technologies and Methods in MEMS Design (MEMSTECH) Polyana, UKRAINE, 18-22 April, 2018 p. 155-160.

10. Tremblay T. Introducing Autodesk Inventor 2009 and Autodesk Inventor LTTM 2009. Indianapolis, Indiana: Wiley Publishing Inc., 2008. Weerasinghe, R. M., Aroos, M. S. M., Pannila, A. S., Jayananda, M. K. and Sonnadara, D. U. J., Construction of an automated weather station for ground-level weather measurements, Proceedings of Institute of Engineers Sri Lanka, 105, (2011) 450.

11. Zhen Fang, Zhan Zhao, Xunxue Cui, LiDong Du, Daoqu Geng, Yundong Xuan, Jing Xu, ShaoHua Wu, "Micro-Sensor Network Node Design for Meteorological Parameter Monitoring", IEEExplore 263 ICRTEDC -2014.

12. https://confluence.cornell.edu/display/SIMULATION/FLUENT+Turbu-lent+Pipe+Flow. 
А. Здобицький, О. Матвійків, М. Лобур, Т. Климкович, Н. Бокла Національний університет "Львівська політехніка"

\section{ПОРТАТИВНА СИСТЕМА ВІДБОРУ ПРОБ РІДКИХ АТМОСФЕРНИХ ОПАДІВ}

() Здобицький А.,Матвійків О., Лобур М., Климкович Т., Бокла Н., 2019

У роботі розглянуто можливість визначення постійних та випадкових джерел забруднення навколишнього середовища за рівнем забрудненості рідких атмосферних опадів. Окреслено проблематику забору проб рідких атмосферних опадів та моніторингу концентрації забруднень за часом випадіння атмосферних опадів. Обгрунтовано доцільність розробки портативної системи, що дозволяє здійснювати забір проб рідких атмосферних опадів у автономному режимі в різних часових інтервалах та періодах випадіння дощу, незалежно від місця його встановлення. Описано конструктивні особливості електричної та механічної частин пристрою, а також алгоритм їх роботи. Наведено результати моделювання та перевірки роботоздатності портативного пристрою за якими визначено його сумарний масовий забір води.

Ключові слова: атмосферні опади, портативна система, пристрій, приводна шестерня, забір проб, забруднення, керуюча плата, давач. 